Мобільні і стаціонарні енергозасоби та їх елементи Mobile and stationary power units and their elements

УДК 631.362

https://doi.org/10.37700/enm.2020.4(18).14 - 23

\title{
Динаміка одинарних та здвоєних колісних систем трактора у вертикальному напрямку
}

\author{
І. В. Галич ${ }^{1}$, Р. В. Антощенков ${ }^{2}$, В. М. Антощенков ${ }^{3}$, С. М. Дюндик ${ }^{4}$, Ю. Г. Жарко \\ 1, 2, 3 Харківський національний технічний університет сільського господарства \\ імені Петра Василенка (м. Харків, Україна), \\ ${ }_{4}^{4}$ Національна академія Національної гвардії України (м. Харків, Україна), \\ 5 Державне підприємство «Харківський регіональний науково-виробничий \\ центр стандартизації, метрології та сертифрікації» (м. Харків, Україна), \\ email:1 galich-ivan@ukr.net; 2 roman.antoshchenkov@gmail.com; \\ 3 viktor.tiaxntusg@gmail.com, 4 sdundik15@gmail.com; 5 090sert@gmail.com; \\ ORCID: ${ }^{1}$ 0000-0002-9137-036X; ${ }^{2}$ 0000-0003-0769-7464; \\ ${ }^{3}$ 0000-0002-1136-5430; ${ }^{4}$ 0000-0003-3558-0028
}

В роботі наведено результати досліджень динаміки одинарних та здвоєних колісних систем трактору у вертикальному напрямку в залежності від профілю опорної поверхні. Дослідження виконано для одинарних та здвоєних колісних систем тракторів серії ХТЗ-240.

В роботі наголошено, що підвищення продуктивності та ефективності використання машиннотракторних агрегатів досягається за рахунок збільшення робочих швидкостей, ширини обробітку та раціонального використання сільськогосподарських машин, що входять до складу агрегатів. При цьому, як нерівність поверхні поля так і швидкість руху є джерелами додаткових коливань та вібрацій агрегату. Додаткові коливання складових елементів трактора призводять до збільшення переущільнення ґрунту. Для кращого розуміння цього процесу необхідно враховувати фізику реакції шин на нерівності поверхні поля, зокрема вплив еластичної частини колеса.

Математична модель колеса, що включає коефіцієнт опору кочення, який залежить від тиску в шині і швидкості. Складено еквівалентну динамічну модель одинарних та здвоєних колісних систем, що рухається по опорній поверхні в MatLab\Simulink.

Визначено, що мінімальний радіус одиночного колеса дорівнює 0,7599 м, а максимальний 0,8605 м. Відповідно, розмах коливань радіусу одинарного колеса складає 0,1006 м. Радіус здвоєного колеса має мінімальне значення 0,75 м, максимальне - 0,820 м та розмах - 0,07 м. Розмах коливань радіусу здвоєних коліс нижче на 0,03 м ніж для одинарних коліс. Здвоєне колесо має нижчу амплітуду та розмах коливань швидкості центру мас у вертикальному напрямі ніж одинарне колесо. Здвоєне колесо має меншу деформацію у вертикальному напряму, тобто динамічний радіус залишається більш стабільним.

Сформовано передатні функції залежності швидкості центра мас колеса у вертикальному напрямі від швидкості зміни висоти профілю опорної поверхні для одинарних та здвоєних колісних систем. Розраховано логарифмічно амплітудно-фазову частотну характеристики одинарних та здвоєних коліс у вертикальному напрямі.

Ключові слова: динаміка, колесо, трактор, буксування, швидкість, динамічний радіус.

Вступ. Відомо, що підвищення продуктивності та ефективності використання машиннотракторних агрегатів (МТА) досягається за допомогою збільшення робочих швидкостей, ширини обробітку та раціонального використання сільськогосподарських машин, що входять до складу агрегатів [1]. При цьому, як нерівність поверхні поля так і швидкість руху є джерелами додаткових коливань та вібрацій MTA $[2,3]$. Детальне визначення характеристик нерівностей полів може сприяти підвищенню якості та ефективності технічних рішень, які покращують динаміку МТА, знижують рівні вібрацій та коливань, поліпшують умови праці механізатора. Міжнародний стандарт ISO 8608:2016 [4] описує методику проведення досліджень вертикальних прискорень, які виникають від впливу профілів поверхні, вказуючи на зв'язки між шорсткістю профілю та механічними руйну- 
ваннями включаючи дискомфорт механізатора [5, 6]. При цьому не визначено жодних прямолінійних методів вимірювання профілю поверхні або приладів, що підтверджують достовірність проведення таких досліджень [7, 8].

Додаткові коливання складових елементів трактора призводять до збільшення переущільнення ґрунту. А це ускладнює пророщування рослин і призводить до зниження родючості ґрунтів та порушення агротехнічних вимог, створення несприятливих умов вирощування рослин (порушується глибина обробітку ґрунту, закладення насіння, тощо). Також, коливання знижують тягово-зчіпні властивості трактора, погіршують умови праці водія працездатність, надають шкідливий вплив на роботу механізмів, викликаючи їх передчасний знос [9].

Аналіз останніх досліджень і публікацій. Методи прямого вимірювання профілю поверхні поля під час роботи МТА (наприклад, за допомогою оптичної технології) не мають необхідної точності або повторюваності, оскільки вони не враховують деформації поверхні, які індукує агрегат [10]. Дійсно, стандартом [4] рекомендовано враховувати додаткові фактори під час проведення позашляхових вимірювань у випадках як м'яких поверхонь (сплощених і відфільтрованих колесами, що рухаються вперед), так і твердих (через фрільтруючий ефект огородження колеса).

При непрямих вимірюваннях профрілю поверхні поля, передбачається проведення двоетапної процедури для вимірювання вертикального прискорення: трактор у складі МТА має працювати на різних поверхнях (в робочих умовах), для отримання даних віброприскорень, яким піддається машина; потім виконується реплікація на стенді (методом деконволюції) раніше набутих даних, поки не буде досягнуто точне відтворення отриманих результатів $[11,12]$.

У експерименті [13], що проведено наведеним методом визначено нерівномірність чотирьох різних поверхонь (як у часовій, так і в частотній величинах). Незважаючи на широку мінливість профрілів поверхонь полів сільськогосподарського призначення, результати експерименту вказують, які особливості, серед характеристик ґрунту та налаштувань трактора (тобто маси баласту чи тиску в шинах), можуть суттєво вплинути динаміку МТА. Згідно з даними експерименту результати показали, що зміна профілю ґрунту та швидкості руху трактора, впливає на прискорення, мають схожі спектральні тенденції, які були визнані актуальними на частотах менше 4 Гц. Цей результат також підтверджено дослідженнями, проведеними при запуску сільськогосподарського трактора в чотирьох режимах налаштування та при чотирьох різних швидкостях руху вперед на стандартній випробувальній доріжці згідно з ISO 5008 [14].
Подальші дослідження $[15,16]$ які порівнювали різні трактори та сільськогосподарські операції підтвердили можливість визначення стандартної тенденції впливу ґрунту. 3 даних досліджень випливає, що у випадку виконання сільськогосподарських робіт, коливання тракторів з вертикальним прискоренням збуджують саме їх еластичні компоненти (тобто шини, кабіна, гумові кріплення тощо). А це, в свою чергу, визначає загальну динаміку МТА.

Для кращого розуміння цього процесу необхідно враховувати фрізику реакції шин на нерівності на поверхні поля, зокрема вплив еластичної частини МТА, коли колесо проходить з постійною швидкістю по шпильці, довжина якої набагато менша за довжину контакту, що призводить до зміни в радіусі кочення шини. В роботах [17] та [18] наголошено на необхідність взяти до уваги чотири основні фактори:

- властивості покриття шини (зміни вертикальних та поздовжніх сил, а також кутової швидкості колеса);

- ефективна дорожня площина (ефективна висота та нахил короткої трапецієподібної скоби апроксимації на осі на половину синусоїди);

- ефективний радіус кочення при коченні по котушці (приріст при нормальному навантаженні, місцевий нахил вперед, місцева кривизна вперед);

- той факт, що виміряна вібрація є чисто вертикальною, тоді як на тестовій доріжці є сума вертикальної та поздовжньої складових.

Мета роботи. Теоретично дослідити динаміку одинарних та здвоєних колісних систем трактора та визначити вплив профілю опорної поверхні на коливання трактора вертикальному напрямку.

Результати досліджень. Власне кажучи, переміщення маточини шини, що обертається, як через кочення, так і через радіальний відхил, який виникає в наслідок проходу через перешкоду, можна описати синусоїдальним законом (рис. 1).

Можна зробити висновок, що, навіть незважаючи на те, що пониження швидкості руху до мінімальної характеристики показує амплітудну характеристику маточини, реакція МТА визначається пружними властивостями його компонентів, незалежно від прямого збудження або випадковості профрілю тестової доріжки. Така сама $€$ реакція шин та сидіння на нерівності, що головним чином впливає на комфорт оператора.

Тому можна стверджувати, що стандартні випробування повинні мати на меті забезпечення вхідної сили, яка, збуджуючи основні частоти MTA, репрезентує частоти, які впливають на комфорт оператора під час виконання робочого процесу.

Як результат, щоб уникнути складних випробувальних доріжок, вертикальна динаміка трактора, а також випробування на комфорт та стійкість матеріалів на витривалість можуть бути 
значно спрощені та стандартизовані. При цьому, ні випробування в лабораторії, ні на відкритому ґрунті не вимагають, щоб трактор працював на декількох випробувальних коліях, забезпечуючи вимоги різноманітних вертикальних коливань, оскільки для цього достатньо розробити одну шорстку випробувальну поверхню, яка б працювала 3 такою швидкістю, щоб дослідити пружності частин трактора [19].
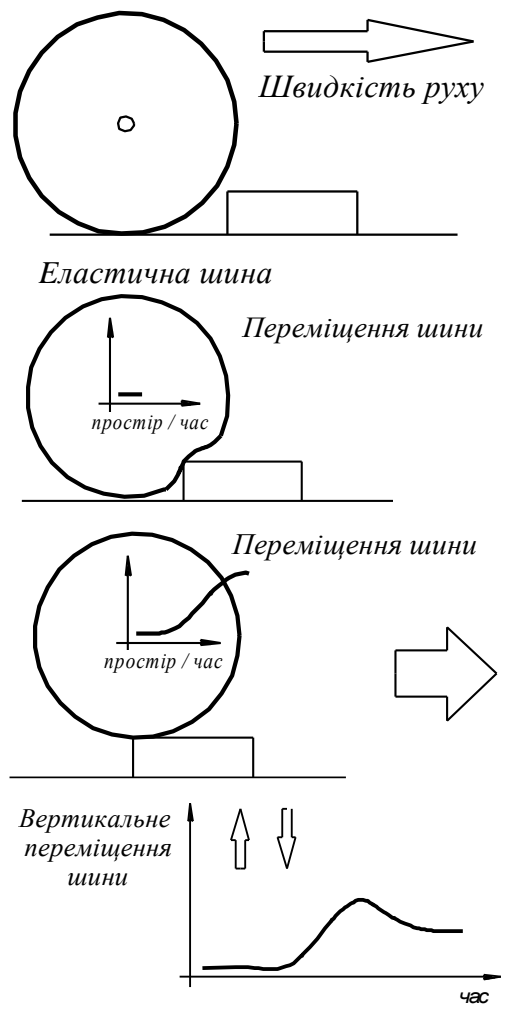

Рис. 1. Схема відгуку колеса на збурення в наслідок проходу через перешкоду

В процесі роботи МТА піддається впливу безлічі зовнішніх факторів, що призводять до зміни вертикальних навантажень на ходову частину та двигун. Наприклад, це неоднорідності фрізико-механічних властивостей оброблюваного ґрунту, нерівності дорожнього полотна, нерівномірність тягового опору з боку агрегатованої сільськогосподарської машини. Ці впливи носять, випадковий характер і описуються випадковими функціями. Крім того, сам машинно-тракторний агрегат, його двигун або трансмісія також є джерелами коливань та вібрацій.

Наприклад, в роботі [20] досліджено енергетичні показники функціонування одинарних та здвоєних колісних систем, а в [21-23] визначено відмінності ущільнення ґрунту. Рух трактора у складі МТА по полю підчас виконання технологічних операцій виробництва продукції рослинництва супроводжується буксуванням ведучих коліс [24]. Буксування коліс трактора знаходиться у межах від 0 до 15\%, тому необхідно його враховувати при дослідженнях динаміки трактора. На буксування впливає багато факторів такі, як навантаження на колесо [25], момент [26] та тиск в шинах, тощо. Тому всі перераховані фрактори необхідно враховувати.

Складено динамічну модель колеса, що враховує перелічені вище фактори та таку модель наведено на рис. 2.

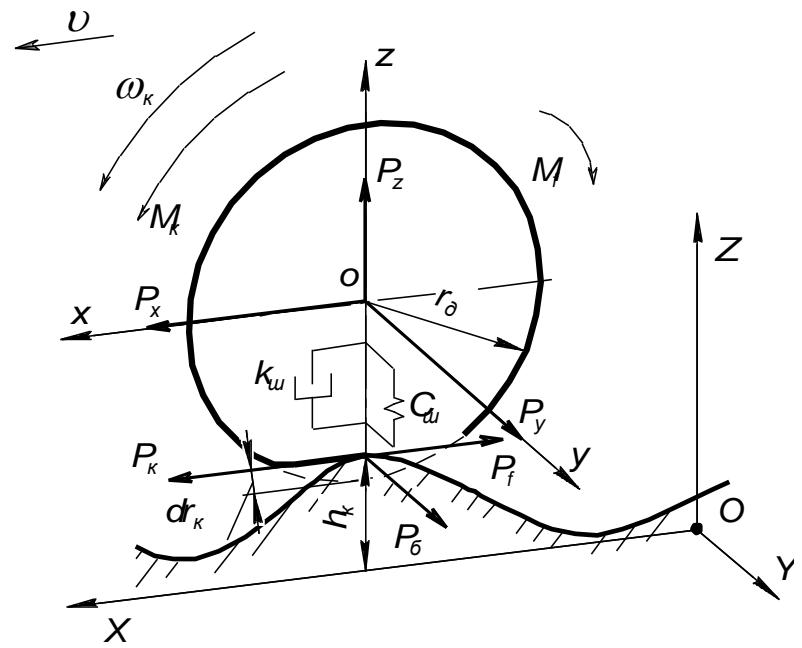

Рис. 2. Динамічна модель колеса $X O Y Z$ - глобальна (нерухлива) система координат; хоуz - зв'язана система координат; $\omega_{k}$ - кутова швидкість обертання; $v$ - поступова швидкість руху; $h_{k}$ - висота профрілю ґрунту; $r_{\text {д }}$ - динамічний радіус колеса; $d r_{\text {к }}-$ динамічна деформація колеса у вертикальному напрямі; $P_{x}, P_{y}, P_{z}-$ сили, що діють на колесо прикладені до його центра; $P_{k}$ - дотична сила тяги; $M_{k}$ - крутний момент; $P_{f}, M_{f}-$ сила та

момент опору кочення; $P_{\delta}-$ сила бічного уводу; $k_{ш}$ і $C_{\text {ш }}-$ податливість та жорсткість шини у вертикальному напрямі

Математична модель колеса, що включає коефіцієнт опору кочення, який залежить від тиску в шині і швидкості має вигляд:

$$
\left\{\begin{array}{c}
J_{\text {кij }} \dot{\omega}_{\text {к } i j}=M_{\text {кij }}-r_{\text {дij }} \times \\
\times\left(P_{\text {к } i j}-\left(\frac{P_{i j}}{P_{0 i j}}\right)^{\alpha}\left(\frac{P_{Z i j}}{P_{z 0 i j}}\right)^{\beta} \times\right. \\
\left.\times P_{z 0 i j}\left(A+B\left|v_{C i j}\right|+C v_{C i j}^{2}\right)\right), \\
\omega_{\text {к } i j}=\frac{v_{C_{i j} x y}}{r_{\text {дij }} \delta_{\text {к } i j}}, \\
r_{\text {дij }}=r_{\text {к } i j}-d r_{\text {к } i j} .
\end{array}\right.
$$

де $P, P_{0}$ - дійсний та номінальний тиск у шині; $P_{z}, P_{z 0}-$ дійсне та номінальне навантаження на 
колесо; $\alpha, \beta, A, B, C$ - апроксимуючі коефіцієнти; $\delta_{\text {кij }}$ - буксування коліс трактора, методи визначення якого наведено у роботах [20, 24-27].

Як наголошено раніше, трактора серії ХТЗ-240К можуть обладнуватись одинарними та здвоєними колісними системами [27]. Виконано дослідження динаміки одинарних колісних систем у вертикальному напрямі. Складено еквівалентну динамічну модель одинарного колеса, що рухається по опорній поверхні в MatLablSimulink (рис. 3).

Форма профрілю опорної поверхні описано гармонійною функцією. Визначено швидкості зміни висоти профрілю опорної поверхні та центру мас одинарного колеса у вертикальному напрямі та наведено на рис. 4. Розраховано висоту профрілю опорної поверхні.

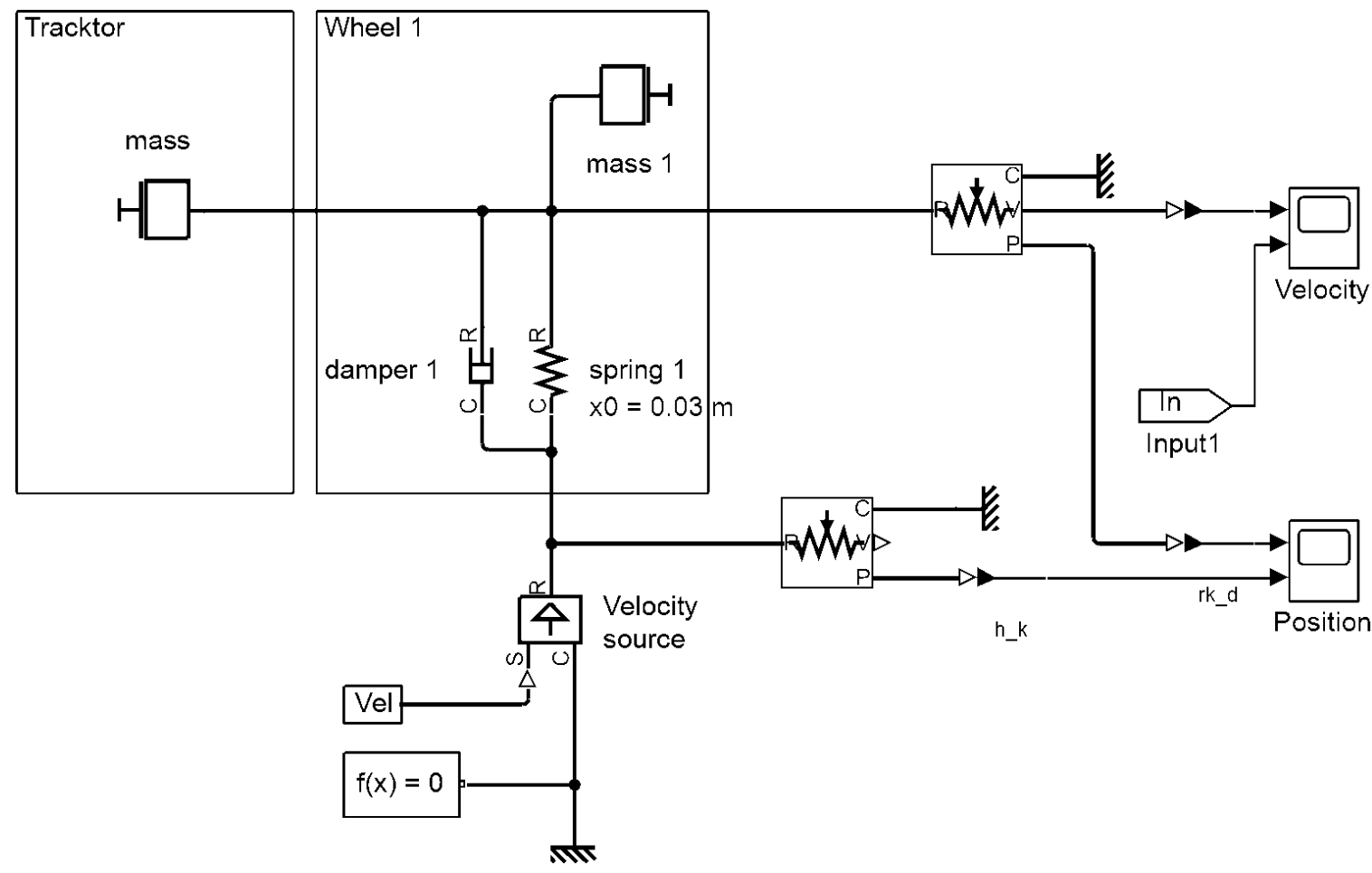

Рис. 3. Модель одинарного колеса в MatLab/Simulink

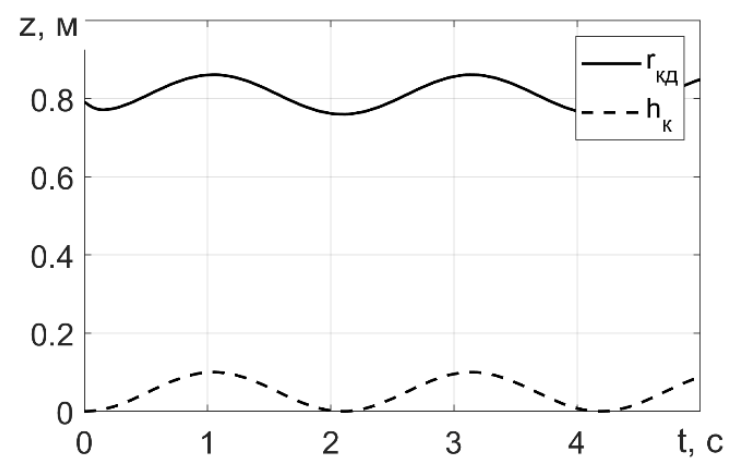

a

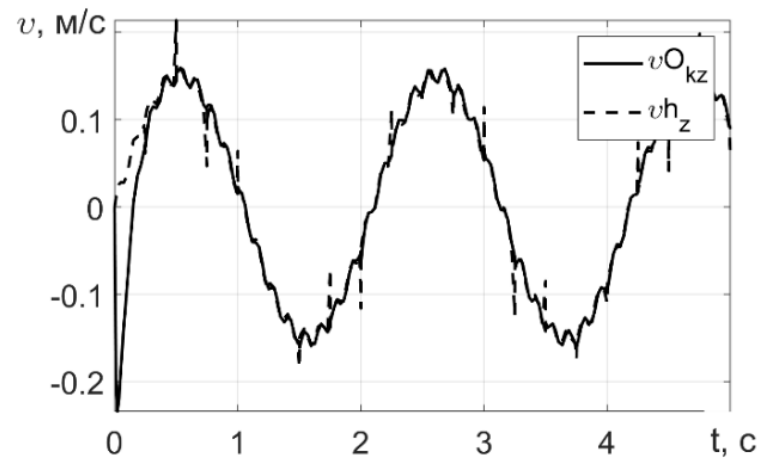

6

Рис. 4. Залежності висот (а) та швидкостей (б) профрілю опорної поверхні і центру мас колеса від часу для одиночного колеса

Розмах коливань профілю опорної поверхні складає 0,1 м з періодом 2,11 с (рис. 4, а). Мінімальний радіус одинарного колеса дорівнює 0,7599 м, а максимальний - 0,8605 м. Відповідно, розмах коливань радіусу одинарного колеса складає 0,1006 м з періодом 2,11 с.
Амплітуда, розмах та період коливань швидкості зміни висоти профілю опорної поверхні $v h_{z}$ та швидкості центра мас колеса у вертикальному $v O_{\text {кz }}$ напрямі співпадають (рис. 4, б). Також співпадають фази. Мінімальне значення $v h_{z}$ та $v O_{\text {кz }}$ складають - 0,14 м/с, максимальне - 0,157 м/с, 
розмах - 0,297 м/с та періодом коливань 2,11 с.

Передатна функція залежності швидкості центра мас колеса у вертикальному напрямі $v O_{\text {кz }}$ від швидкості зміни висоти профрілю опорної поверхні $v h_{z}$ має вигляд:

$$
H(s)=\frac{78,24 \cdot s^{2}+38,08 \cdot s+673,1}{s^{3}+8,526 \cdot s^{2}+46,73 \cdot s+41,46} .
$$

Розраховано логарифммічну амплітудно-фразову частотну характеристику швидкості центра мас колеса у вертикальному напрямі $v O_{\text {кz }}$ о формули (2) та наведено на рис. 5.
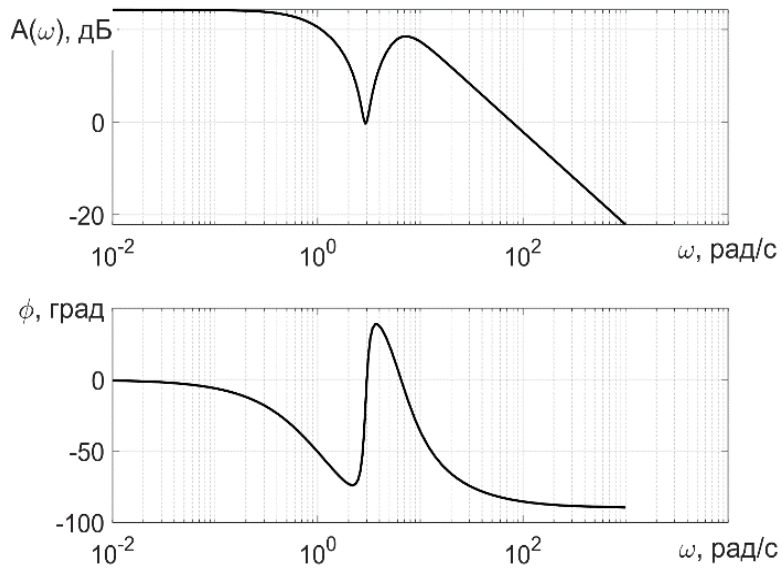

Рис. 5. Логарифрмічна амплітудно-фразова частотна характеристика залежності швидкості центра мас одинарного колеса у вертикальному напрямі від швидкості зміни висоти профілю опорної поверхні

Складено схему здвоєних коліс (рис. 6, а) та еквівалентну модель з пружних та дисипативних елементів (рис. 6, б). Здвоєне колесо опирається на опорну поверхню посередині між зовнішнім та внутрішнім колесами. Пружність та податливість шин у вертикальному напрямі для зовнішнього та внутрішнього колеса співпадають.

Для здвоєного колеса теоретично досліджено динаміку у вертикальному напрямі. Складено еквівалентну динамічну модель здвоєного колеса, що рухається по опорній поверхні в MatLab\Simulink (рис. 7).

Розраховано швидкості зміни висоти профілю опорної поверхні та центру мас здвоєного колеса у вертикальному напрямі та наведено на рис. 8, а та визначено висоту профрілю опорної поверхні. Розраховано залежності швидкостей профрілю опорної поверхні та центру мас здвоєного колеса від часу у вертикальному напрямі (рис. 8).

Радіус здвоєного колеса має мінімальне значення 0,75 м, максимальне - 0,820 м та розмах 0,07 м (рис. 8, а). Період коливань радіусу здвоєного колеса співпадає періоду коливань одинарного (рис. 4 , а) та дорівнює 2,11 с. Таким чином, розмах коливань радіусу здвоєних коліс нижче на 0,03 м ніж для одинарних коліс. Форма профрілю опорної поверхні для дослідження динаміки одинарних та здвоєних коліс однаковий.

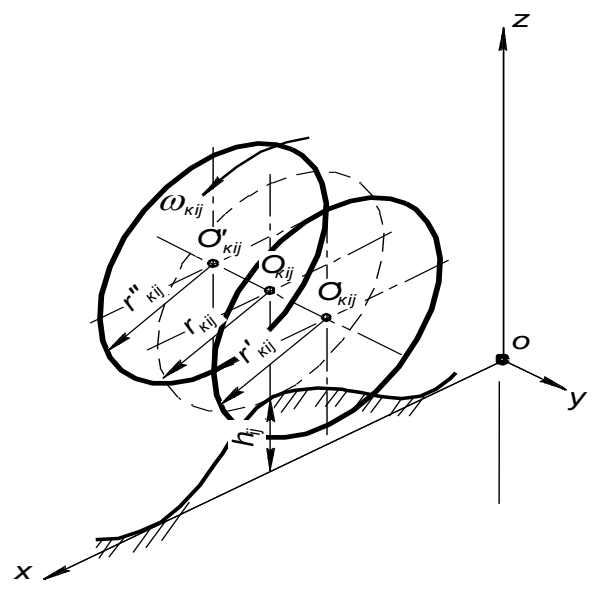

a

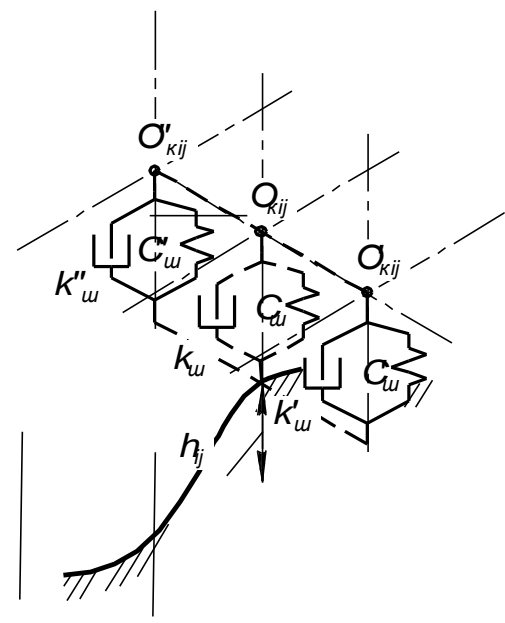

6

Рис. 6 Схема здвоєних коліс трактора (а) та еквівалентна модель (б)

Здвоєне колесо має нижчу амплітуду та розмах коливань швидкості центру мас у вертикальному напрямі (рис. 8, а) ніж одинарне колесо. Відповідно, розмах коливань швидкості центру мас здвоєного колеса $v O_{\text {кz }}$ має значення 0,204 м/с, мінімальна швидкість - 0,105 м/с та максимальне - 0,09 м/с (рис. 8, б).

Передатна функція залежності швидкості центра мас здвоєного колеса у вертикальному напрямі $v O_{\text {кz }}$ від швидкості зміни висоти профрілю опорної поверхні $v h_{z}$ має вигляд:

$$
H(s)=\frac{33,42 \cdot s^{2}-3,317 \cdot s+195,7}{s^{3}+14,42 \cdot s^{2}+40,72 \cdot s+12,57} .
$$

Розраховано логарифмічну амплітудно-фразову частотну характеристику швидкості центра мас здвоєного колеса у вертикальному напрямі $v O_{\text {Kz }} 3$ форомули (3) та наведено на рис. 9. 


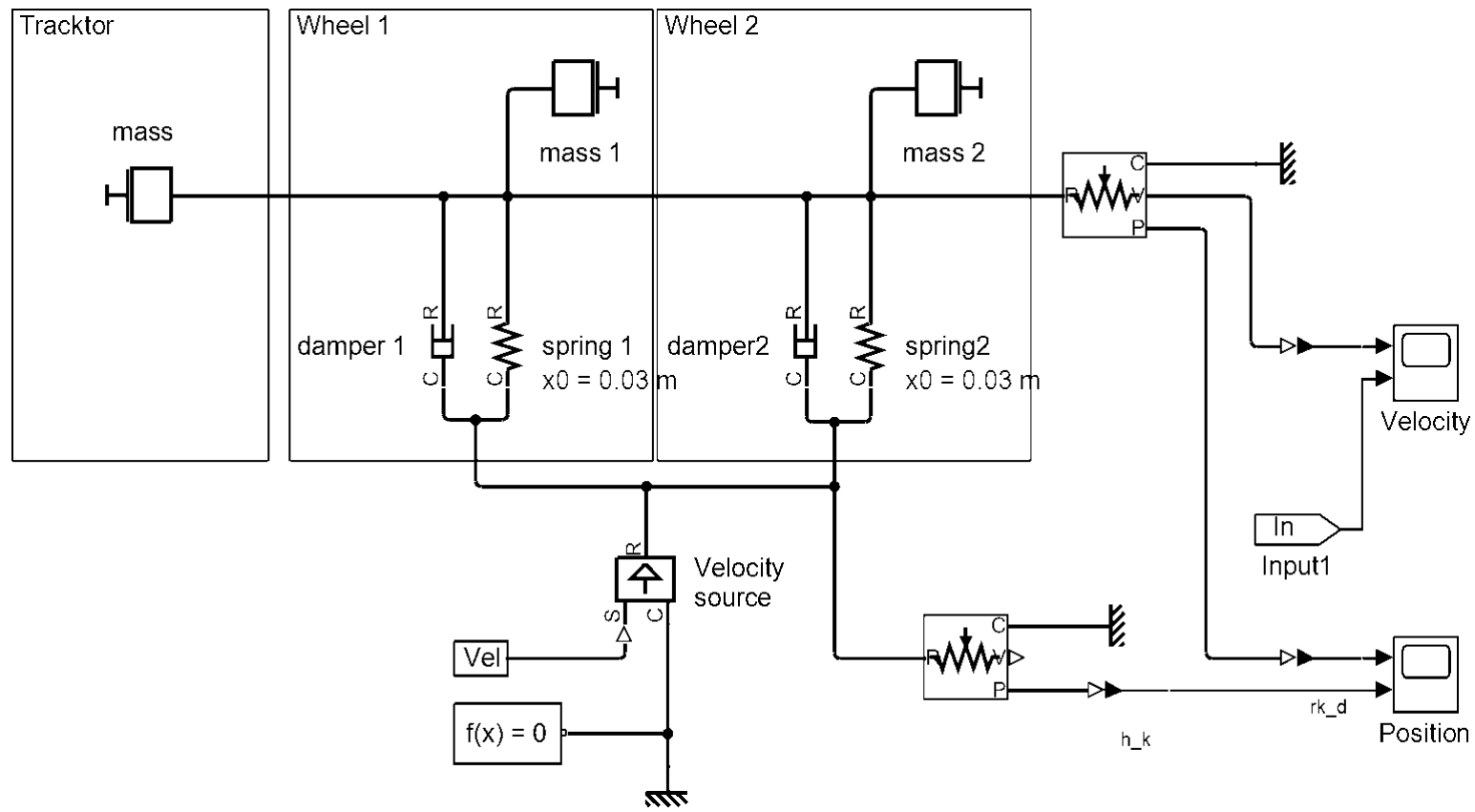

Рис. 7. Модель здвоєного колеса в MatLablSimulink
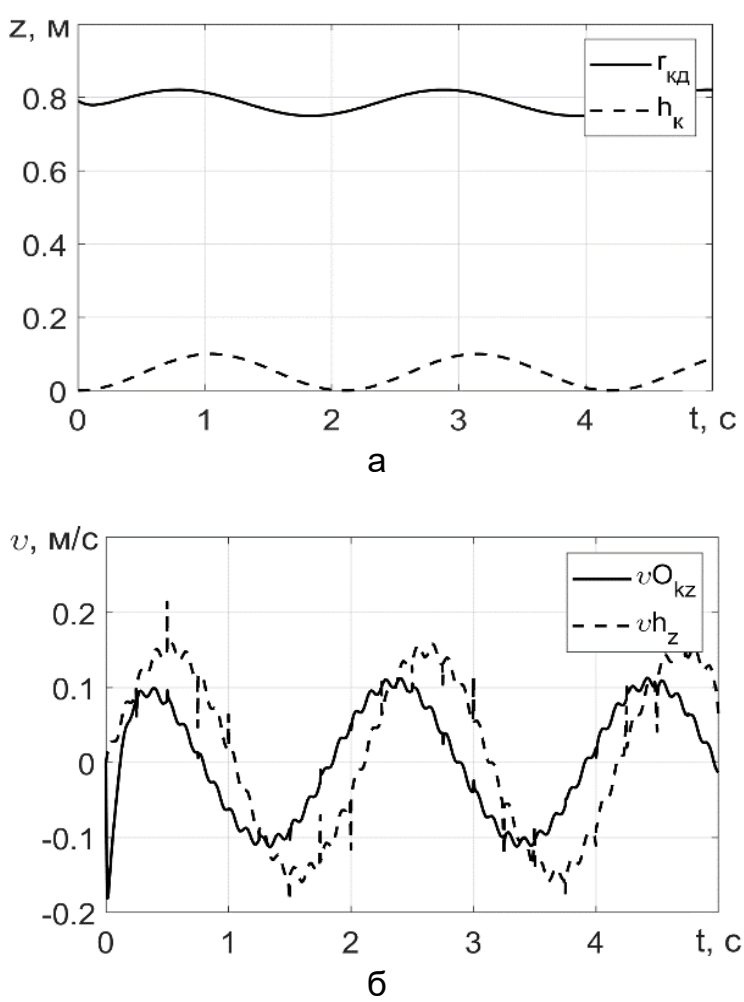

Рис. 8. Залежності швидкостей профрілю опорної поверхні та центру мас здвоєного колеса від часу

Необхідно зазначити, що здвоєне колесо має нижчі показники динаміки у вертикальному напрямі ніж одинарне. Період коливань дорівнює
2,11 с. Однак, швидкість центру мас колеса у вертикальному $v O_{\text {кz }}$ по фразі не співпадає із швидкістю зміни висоти профрілю опорної поверхні

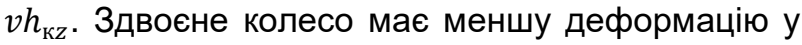
вертикальному напряму, тобто динамічний радіус залишається більш стабільним.
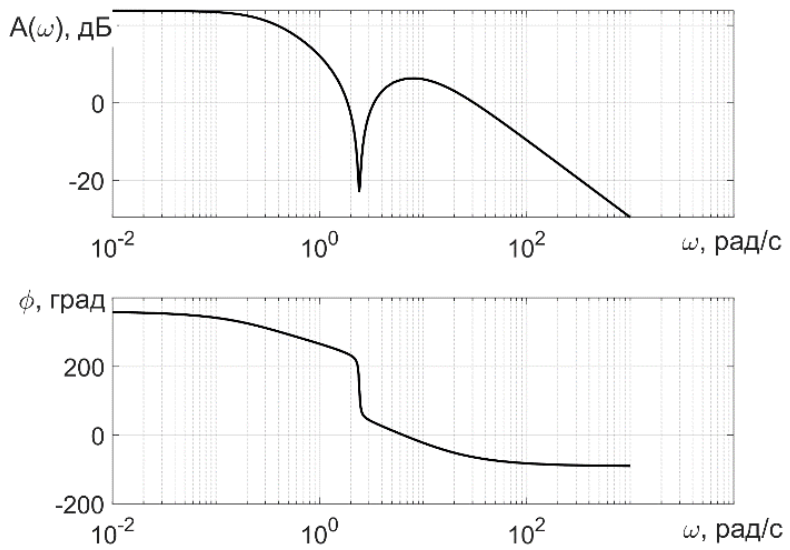

Рис. 9. Логарифрмічна амплітудно-фразова частотна характеристика залежності швидкості центра мас здвоєного колеса у вертикальному напрямі від швидкості зміни висоти профілю опорної поверхні

Висновки.

1. Колісні трактора серії ХТ3-240К можуть обладнуватись одинарними та здвоєними колісними системами. Виконано дослідження динаміки одинарних та здвоєних колісних систем у 
вертикальному напрямі в залежності від профілю опорної поверхні. Визначено вплив профілю опорної поверхні на динаміку колеса у вертикальному напрямі.

2. Визначено, що мінімальний радіус одиночного колеса дорівнює 0,7599 м, а максимальний - 0,8605 м. Відповідно, розмах коливань радіусу одинарного колеса складає 0,1006 м. Радіус здвоєного колеса має мінімальне значення 0,75 м, максимальне - 0,820 м та розмах - 0,07 м. Розмах коливань радіусу здвоєних коліс нижче на 0,03 м ніж для одинарних коліс. Здвоєне колесо має нижчу амплітуду та розмах коливань швидкості центру мас у вертикальному напрямі ніж одинарне колесо. Здвоєне колесо має меншу деформацію у вертикальному напряму, тобто динамічний радіус залишається більш стабільним.

3. Сфрормовано передатні функції залежності швидкості центра мас колеса у вертикальному напрямі від швидкості зміни висоти профілю опорної поверхні для одинарних та здвоєних колісних систем. Розраховано логарифмічно амплітуднофазову частотну характеристики одинарних та здвоєних коліс у вертикальному напрямі.

\section{Література:}

1 Галич І.В., Антощенков Р.В. До аналізу впливу коливань елементів машинно-тракторного агрегату на динамічні та експлуатаційні показники. Науковий журнал «Технічний сервіс агропромислового, лісового та транспортного комплексів». Харків, №9. 2017. С 103-107.

2 Scarlett A.J., Price J.S. Stayner R.M. Whole body vibration: Evaluation of emissions and exposure levels arising from agricultural tractors. J. Terramech. 2007, 44, 65-73.

3 Deboli R., Calvo A., Preti C. Comparison between ISO 5008 and Field Whole Body Vibration Tractor Values. J. Agric. Eng. 2012,43.

4 ISO 8608:2016 Mechanical Vibration - Road Surface Profiles - Reporting of Measured Data, International Standardization Organization, Second edition 2016-11-01.

5 Roman L., Florea A., Cofaru I. Software Application for assessment the reliability of suspension system at Opel cars and of road profiles. Fascicle Manag. Technol. Eng. 2014,1, 289-294.

6 Agostinacchio M., Ciampa D., Olita S. The vibrations induced by surface irregularities in road pavements - A Matlab approach. In European Transport. Research Review, 2013th ed.; Springer: Berlin/Heidelberg, Germany, 2013.

7 Park S., Popov A.A., Cole D.J. Influence of soil deformation on off-road heavy vehicle suspension vibration. J. Terramech. 2004, 441,41-68.

8 Gonzalez A., O'brien E.J., Li Y.Y., Cashell K. The use of vehicle acceleration measurements to estimate road roughness. Veh. Syst. Dyn. 2008, 46,483-499.
9 Антощенков Р.В., Галич І.В. Дослідження коливань елементів машино-тракторного агрегату. Матеріали міжнародної науково-практичної конференції «Експлуатаційна та сервісна інженерія». Харків: ХНТУСГ, 2020. С. 92-93.

10 Fassbender F.R., Fervers C.W., Harnisch C. Approaches to predict the vehicle dynamics on soft soil. Veh. Syst. Dyn. 1997, 27,173-188.

11 Bisaglia C., Cutini M., Gruppo G. Assessment of vibration reproducibility on agricultural tractors by a "four poster test stand". In Proceedings of the XVI CIGR. EurAgEng 2006 64th VDI-MEG and FAO joint "World Congress - Agricultural Engineering for a Better World", Bonn, Germany, 3-7 September 2006.

12 Anthonis J., Vaes D., Engelen K., Ramon H., Swevers J. Feedback Approach for Reproduction of Field Measurements on a Hydraulic Four Poster. Biosyst. Eng. 2007, 96,435-445.

13 Cutini M., Bisaglia C., Bertinotti S.A. Power spectral analysis of agricultural field surface. In Proceedings of the XVII World Congress of the International Commission of Agricultural and Biosystem. Engineering, Quebec, QC, Canada, 13-17 June 2010.

14 Cutini M., Deboli R., Calvo A., Preti C., Inserillo M., Bisaglia C. Spectral analysis of a standard test track profile during passage of an agricultural tractor. J. Agric. Eng. 2013, 44 (Suppl. 1), 719-723.

15 Cutini M., Bisaglia C. Procedure and layout for the development of a fatigue test on an agricultural implement by a four poster test bench. J. Agric. Eng. 2013, 44, 402-405.

16 Cutini M., Bisaglia C. Experimental identification of a representative soil profile to investigate Tractor Operator's Discomfort and Material Fatigue Resistance. In Proceedings of the International Conference of Agricultural Engineering (AgEng 2014 Zurich), Zurich, Switzerland, 6-10 July 2004; p. 8.

17 Pacejka H.B. Tyre and Vehicle Dynamics, 2nd ed.; Butterworth Heinemann: Oxford, UK, 2010.

18 Jianmin G., Gall R., Zuomin W. Dynamic Damping and Stiffness Characteristics of the Rolling Tire. Tire Sci. Technol. 2001, 29, 258-268.

19 Cutini M., Deboli R., Calvo A., Preti C., Brambilla M., Bisaglia C. Ground Soil Input Characteristics Determining Agricultural Tractor Dynamics. Appl. Eng. Agric. 2017, 33

20 Калінін Є.І. Оцінка впливу встановлення здвоєних шин на буксування рушіїв трактора в складі орного агрегату на агрофоні підвищеної вологості. Ресурсозберігаючі технології, матеріали та обладнання у ремонтному виробництві. Вісник ХНТУСГ ім. П. Василенка. 2010. Вип. 96. С. 382-391.

21 Соларьов О.О. Експериментальні дослідження ущільнюючого впливу на ґрунт рушіїв трактора МТ3-82. Вісник Сумського національного університету. Сер.: Механізація та автоматизація виробничих процесів. Суми: СНАУ, 2016. Вип. 3 (28). С. 147-153. 
22 Довжик М.Я. Татьянченко Б.Я., Соларев А.А. Оценка уплотнения грунта под следом колеса транспортного средства. Вісник ХНТУСГ ім. П. Василенка. «Технічний сервіс машин для рослинництва». 2014. Вип. 145. С. 149-155.

23 Довжик М.Я. Татьянченко Б.Я., Соларев А.А. Расчет уплотнения грунта под колесами транспортных средств с помощью программного обеспечения MS Office. Motrol. Vol. 16, No 7. 2014. C. 131-133.

24 Lu Xiong and Zhuoping Yu. Vehicle Dynamic Control of 4 In-Wheel-Motor Drived Electric Vehicle, Electric Vehicles - Modelling and Simulations, Seref Soylu, IntechOpen.

25 Garcia-Pozuelo, D., Yunta, J., Olatunbosun, O., Yang, X., \& Diaz, V. A Strain-Based Method to Estimate Slip Angle and Tire Working Conditions for Intelligent Tires Using Fuzzy Logic. Sensors (Basel, Switzerland), 2017. 17(4), 874.

26 Lee C., Hedrick K., Yi, K. Real-Time Slip-Based Estimation of Maximum Tire-Road Friction Coefficient. IEEE/ASME Trans. Mech. 2004, 9, 454-458.

27 Мельник В.І., Антощенков Р.В., Антощенков В.М., Кісь В.М., Галич І.В. Результати експериментальних досліджень тягової динаміки трактора ХТЗ-243К. Вісник ХНТУСГ імені П. Василенка. 2019. Вип. 198. 2019. С. 181-187.

\section{References:}

1 Halych, I. and Antoshhenkov, R., 2017. Do analizu vplyvu kolyvanj elementiv mashynnotraktornogho aghreghatu na dynamichni ta ekspluatacijni pokaznyky. Tekhnichnyj servis aghropromyslovogho, lisovogho ta transportnogho kompleksiv, 9, pp.103-107.

2 Scarlett, A., Price, J. and Stayner, R., 2007. Whole-body vibration: Evaluation of emission and exposure levels arising from agricultural tractors. Journal of Terramechanics, 44(1), pp.65-73.

3 Deboli, R., Calvo, A. and Preti, C., 2012. Comparison between ISO 5008 and field whole body vibration tractor values. Journal of Agricultural Engineering, 43(2), p.8.

4 2016. Mechanical Vibration - Road Surface Profiles - Reporting Of Measured Data ISO 8608. Geneva: ISO.

5 Roman, L., Florea, A. and Cofaru, I., 2014. Software application for assessment the reliability of suspension system at opel cars and of road profiles. Annals of the oradea university. Fascicle of Management and Technological Engineering., XXIII (XIII), 2014/1(1).

6 Agostinacchio, M., Ciampa, D. and Olita, S., 2013. The vibrations induced by surface irregularities in road pavements - a Matlab $₫$ approach. European Transport Research Review, 6(3), pp.267-275.

7 Park, S., Popov, A. and Cole, D., 2004. Influence of soil deformation on off-road heavy vehicle suspension vibration. Journal of Terramechanics, 41(1), pp.41-68.
8 González, A., O'brien, E., Li, Y. and Cashell, K., 2008. The use of vehicle acceleration measurements to estimate road roughness. Vehicle System Dynamics, 46(6), pp.483-499.

9 Halych, I. and Antoshhenkov, R., 2020. Doslidzhennja kolyvanj elementiv mashynotraktornogho aghreghatu. Ekspluatacijna ta servisna inzhenerija, pp.92-93.

10 Fassbender, F., Fervers, C. and Harnisch, C., 1997. Approaches to predict the vehicle dynamics on soft soil. Vehicle System Dynamics, 27(sup001), pp.173-188.

11 Bisaglia C., Cutini M., Gruppo G., 2006. In Proceedings of the XVI CIGR. EurAgEng 2006 64th VDI-MEG and FAO joint "World Congress - Agricultural Engineering for a Better World". Bonn, Germany: Assessment of vibration reproducibility on agricultural tractors by a "four poster test stand".

12 Anthonis, J., Vaes, D., Engelen, K., Ramon, H. and Swevers, J., 2007. Feedback Approach for Reproduction of Field Measurements on a Hydraulic Four Poster. Biosystems Engineering, 96(4), pp.435-445.

13 Cutini M., Bisaglia C., Bertinotti S.A. 2010. In Proceedings of the XVII World Congress of the International Commission of Agricultural and Biosystem. Engineering, Quebec, QC, Canada: Power spectral analysis of agricultural field surface.

14 Cutini, M., Deboli, R., Calvo, A., Preti, C., Inserillo, M. and Bisaglia, C., 2013. Spectral analysis of a standard test track profile during passage of an agricultural tractor. Journal of Agricultural Engineering, 44(2s).

15 Cutini, M. and Bisaglia, C., 2013. Procedure and layout for the development of a fatigue test on an agricultural implement by a four poster test bench. Journal of Agricultural Engineering, 44(2s).

16 Cutini, M. and Bisaglia, C., 2004. Experimental identification of a representative soil profile to investigate Tractor Operator's Discomfort and Material Fatigue Resistance. In Proceedings of the International Conference of Agricultural Engineering, p.8.

17 Pacejka, H., 2010. Tyres And Vehicle Dynamics. Oxford: Butterworth-Heinemann.

18 Jianmin, G., Gall, R. and Zuomin, W., 2001. Dynamic Damping and Stiffness Characteristics of the Rolling Tire. Tire Science and Technology, 29(4), pp.258-268.

19 Cutini, M., Deboli, R., Calvo, A., Preti, C., Brambilla, M. and Bisaglia, C., 2017. Ground Soil Input Characteristics Determining Agricultural Tractor Dynamics. Applied Engineering in Agriculture, 33(4), pp.509-519.

20 Kalinin, J., 2010. Ocinka vplyvu vstanovlennja zdvojenykh shyn na buksuvannja rushijiv traktora $v$ skladi ornogho aghreghatu na aghrofoni pidvyshhenoji vologhosti. Resursozberighajuchi tekhnologhiji, materialy ta obladnannja u remontnomu vyrobnyctvi. Visnyk KhNTUSGh im. P. Vasylenka, 96, pp.382-391. 
21 Solarjov, O., 2016. Eksperymentaljni doslidzhennja ushhiljnjujuchogho vplyvu na grunt rushijiv traktora MTZ-82. Visnyk Sumsjkogho nacionaljnogho universytetu. Mekhanizacija ta avtomatyzacija vyrobnychykh procesiv, 3(28), pp.147-153.

22 Dovzhyk, M., Tatjjanchenko, B. and Solarev, A., 2014. Ocenka uplotnenyja ghrunta pod sledom kolesa transportnogho sredstva. Tekhnichnyj servis mashyn dlja roslynnyctva. Visnyk KhNTUSGh im. P. Vasylenka, 145, pp.149-155.

23 Dovzhyk, M., Tatjjanchenko, B. and Solarev, A., 2014. Raschet uplotnenyja ghrunta pod kolesamy transportnkh sredstv s pomoshhjju proghrammnogho obespechenyja MS Office. Motrol, 16(7), pp.131-133.
24 Xiong, L. and Zhuoping, Y., 2011. Vehicle Dynamic Control of 4 In-Wheel-Motor Drived Electric Vehicle. Electric Vehicles - Modelling and Simulations, pp.67-80.

25 Garcia-Pozuelo, D., Yunta, J., Olatunbosun, O., Yang, X. and Diaz, V., 2017. A Strain-Based Method to Estimate Slip Angle and Tire Working Conditions for Intelligent Tires Using Fuzzy Logic. Sensors, 17(4), p.874.

26 Lee, C., Hedrick, K. and Yi, K., 2004. RealTime Slip-Based Estimation of Maximum Tire-Road Friction Coefficient. IEEE/ASME Transactions on Mechatronics, 9(2), pp.454-458.

27 Meljnyk, V., Antoshhenkov, R., Antoshhenkov, V., Kisj, V. and Halych, I., 2019. Rezuljtaty eksperymentaljnykh doslidzhenj tjaghovoji dynamiky traktora KhTZ-243K. Visnyk KhNTUSGh imeni P. Vasylenka, 198, pp.181-187.

\title{
Аннотация
}

\section{Динамика одинарных и сдвоенных колесных систем трактора в вертикальном направлении}

\author{
И.В. Галич, Р.В. Антощенков, В.Н. Антощенков, С.М. Дюндик, Ю.Г. Жарко
}

В работе приведены результаты исследований динамики одинарных и сдвоенных колесных систем трактора в вертикальном направлении в зависимости от профиля опорной поверхности. Исследование выполнено для одинарных и сдвоенных колесных систем тракторов серии ХТЗ-240.

В работе отмечено, что повышение производительности и эффективности использования машиннотракторных агрегатов достигается за счет увеличения рабочих скоростей, ширины обработки и рационального использования сельскохозяйственных машин, входящих в состав агрегатов. При этом, как неровность поверхности поля, так и скорость движения являются источниками дополнительных колебаний и вибраций агрегата. Дополнительные колебания составляющих элементов трактора приводят к увеличению переуплотнения почвы. Для лучшего понимания этого процесса необходимо учитывать физику реакции шин на неровности поверхности поля, в частности влияние эластичной части колеса.

Математическая модель колеса включает коэффициент сопротивления качению, который зависит от давления в шине и скорости. Составлено эквивалентную динамическую модель одинарных и сдвоенных колесных систем, движется по опорной поверхности в MatLab \Simulink.

Определено, что минимальный радиус одиночного колеса равен 0,7599 м, а максимальный 0,8605 м. Соответственно, размах колебаний радиуса одинарного колеса составляет 0,1006 м. Радиус сдвоенного колеса имеет минимальное значение 0,75 м, максимальное - 0,820 м и размах - 0,07 м. Размах колебаний радиуса сдвоенных колес ниже на 0,03 м чем для одинарных колес. Сдвоенное колесо имеет ниже амплитуду и размах колебаний скорости центра масс в вертикальном направлении чем одинарное колесо. Сдвоенное колесо имеет меньшую деформацию в вертикальном направления, то есть динамический радиус остается более стабильным.

Сформированы передаточные функции зависимости скорости центра масс колеса в вертикальном направлении от скорости изменения высоты профиля опорной поверхности для одинарных и сдвоенных колесных систем. Рассчитано логарифмически амплитудно-фразовые частотные характеристики одинарных и сдвоенных колес в вертикальном направлении.

Ключевые слова: динамика, колесо, трактор, буксования, скорость, динамический радиус.

\section{Abstract \\ Dynamics of single and double tractor wheel systems in the vertical direction}

\section{I.V. Halych, R.V. Antoshchenkov, V.M. Antoshchenkov, S.M. Diundik, Yu.G. Zharko}

The paper presents the results of studies of the dynamics of single- and double-wheel systems of a tractor in the vertical direction, depending on the profile of the supporting surface. The study was carried out for single and twin wheel systems of tractors of the KhTZ-240 series. 
It is noted in the work that an increase in the productivity and efficiency of the use of machine and tractor units is achieved by increasing the working speeds, working width and rational use of agricultural machines that are part of the units. In this case, both the unevenness of the field surface and the speed of movement are sources of additional vibrations and vibrations of the unit. Additional vibrations of the constituent elements of the tractor lead to an increase in soil compaction. For a better understanding of this process, it is necessary to take into account the physics of the reaction of tires to irregularities in the surface of the field, in particular the effect of the elastic part of the wheel.

The wheel mathematical model includes a rolling resistance coefficient that depends on the tire pressure and speed. An equivalent dynamic model of single- and double-wheel systems has been compiled, it moves along the support surface in MatLab \Simulink.

It is determined that the minimum radius of a single wheel is $0.7599 \mathrm{~m}$, and the maximum is $0.8605 \mathrm{~m}$. Accordingly, the swing of the radius of a single wheel is $0.1006 \mathrm{~m}$. The radius of a double wheel has a minimum value of $0.75 \mathrm{~m}$, a maximum of $0.820 \mathrm{~m}$, and swing $-0.07 \mathrm{~m}$. The swing of the radius of the double wheels is lower by $0.03 \mathrm{~m}$ than for single wheels. A double wheel has a lower amplitude and swing of the velocity of the center of mass in the vertical direction than a single wheel. The twin wheel has less deformation in the vertical direction, that is, the dynamic radius remains more stable.

The transfer functions of the dependence of the speed of the center of mass of the wheel in the vertical direction on the rate of change in the height of the profile of the bearing surface for single- and double-wheel systems are formed. The logarithmic amplitude-phase frequency characteristics of single and double wheels in the vertical direction are calculated.

Keywords: dynamics, wheel, tractor, slippage, speed, dynamic radius.

\section{Бібліографічне посилання/ Bibliography citation: Harvard}

Halych, I. V. et al. (2020) 'Dynamics of single and double tractor wheel systems in the vertical direction', Engineering of nature management, (4(18), pp. 14 - 23.

Подано до редакиії / Received: 02.011.2020 